\title{
Macronutrient and mineral contents of five local black rice (Oryza sativa) cultivars in Indonesia
}

\author{
MUH. NASHRURROKHMAN ${ }^{1}$, PUSPA RESTU SAYEKTI ${ }^{1}$, AYU SAFITRI ${ }^{1}$, YEKTI ASIH PURWESTRI ${ }^{1}$, \\ RARASTOETI PRATIWI, ${ }^{1, \varphi}$ \\ ${ }^{1}$ Department of Tropical Biology, Faculty of Biology, Universitas Gadjah Mada. Jl. Teknika Selatan, Sekip Utara, Sleman 55281, Yogyakarta, Indonesia. \\ Tel./fax.: +62-274-580-839, `email: rarastp@ugm.ac.id \\ ${ }^{2}$ Research Center for Biotechnology, Universitas Gadjah Mada. Jl. Teknika Utara, Sleman 5281, Yogyakarta, Indonesia
}

Manuscript received: 19 August 2019. Revision accepted: 22 November 2019.

\begin{abstract}
Nashrurrokhman M, Sayekti PR, Safitri A, Purwestri YA, Pratiwi R. 2019. Macronutrient and mineral contents of five local black rice (Oryza sativa) cultivars in Indonesia. Biodiversitas 20: 3647-3653. Nutrient composition is important information that can be used to support the development of black rice as functional food. In this study, the macronutrient and mineral compositions of five black rice cultivars were determined by measuring the contents of total carbohydrates, proteins, and lipids, and levels of the minerals Ca, Fe, and $\mathrm{Zn}$ of whole rice, refined rice, and rice bran. Rice samples were obtained from farmers who planted the black rice cultivars of Woja Laka, Toraja, Cempo Ireng "Seyegan", Melik "Bantul" and Wedomartani. Proximate analysis and spectrophotometric methods were performed to measure the contents of macronutrients and minerals. Statistical analysis of all quantitative data was conducted by using One-way analysis of variance (ANOVA) $(\mathrm{p}<0.05)$ using the SPSS-25 program. Results showed that the contents of carbohydrates, proteins, and lipids in the five rice cultivars varied in the range of $61.80 \%-65.58 \%, 7.13 \%-9.10 \%$, and $1.98 \%-3.23 \%$, respectively. Carbohydrates found in refined rice were in the range of 62.71\%-67.89\%, while rice bran had protein and lipid contents varying in the range of $10.95 \%-11.48 \%$ and $5.70 \%-6.86 \%$, respectively. Rice bran also had the highest mineral content and the highest mineral content was $30 \mu \mathrm{g} / \mathrm{g}$ Ca compared to $\mathrm{Fe}$ and $\mathrm{Zn}$. Therefore, the macronutrient and mineral composition varied among the five black rice cultivars and rice components. The highest carbohydrate content was found in refined rice, while the highest proteins, lipids, and minerals $(\mathrm{Ca}, \mathrm{Fe}$, and $\mathrm{Zn})$ contents were found in rice bran.
\end{abstract}

Keywords: Black rice, functional food, macronutrient, micronutrient

\section{INTRODUCTION}

Black rice cultivars belonging to Oryza sativa L. species are widely cultivated in Asia and consumed as staple food and medicine owing to their nutrient contents (Kushwaha 2016). The black color of this rice variety is due to the presence of anthocyanins in the pericarp, aleurone, and endosperm (Kristamtini 2011). Several local black rice cultivars are found in Indonesia, which are named locally based on location and culture, such as Sragen rice, Jlintheng, Pari Ireng, Cempo Ireng, and forbidden rice from China (Kristamtini et al. 2009; Kristamtini et al. 2014). Other black rice cultivars have been introduced and cultivated in other places, such as Aen Metan and Hare Kwa from NTT province, Woja Laka and Laka (originally from NTT province but cultivated in organic paddy field in Malang, East Java), Manggarai from South Sulawesi, Toraja and Bau Bau from Southeast Sulawesi that are cultivated in Java (Budiman et al. 2012; BB Biogen 2010; Shinta et al. 2014). A slight difference in the location of cultivation of black rice cultivars results in a small variation in its morphology (Sa'adah et al. 2013).

Black rice has the potential to be used as functional food due to the presence of bioactive compounds and anthocyanins (Pratiwi and Purwestri 2017). Recent studies have been focusing on the macronutrient and mineral composition of Indonesian local black rice cultivars, such as the amount of amylose and the fiber content of local black rice, and the nutrient profile of Toraja, Melik "Bantul", Cempo Ireng, and Wulung cultivars (Indrasari et al. 2008; Mangiri et al. 2016; Kereh et al. 2016; Ratnaningsih and Ekawatiningsih 2010; Hartati 2013). One study reported trace mineral (iron and zinc) content in black rice was higher than that in white rice (Pratiwi and Purwestri 2017). Another study on the macronutrient content of Toraja cultivar reported the proportion of carbohydrates, lipids, and proteins of $85 \%, 1.9 \%$, and $1.04 \%$, respectively, while minerals such as calcium, magnesium, potassium, iron, and zinc constituted $0.386,1.95,0.886,0.391$, and 0.021 $\mathrm{mg} / \mathrm{ml}$, respectively (Mangiri et al. 2013). Sompong et al. (2011) showed that Thailand and China black rice cultivars, namely Niaw Dam Pleuak Khao, Niaw Dam Pleuak Dam, and China Black Rice, had lipid, protein, and carbohydrate contents of 2.65-2.85, 8.17-10.85, and 71.99$74.09 \mathrm{~g} / 100 \mathrm{~g}$, respectively. Murdifin et al. (2015) stated that variations in taste, color, physicochemical characteristics, and nutrient composition depend on the geographical climate of the region where the cultivar is grown. Each rice cultivar has its own physicochemical and proximate composition (moisture, total energy, protein, carbohydrate, and lipid contents) (Thomas et al. 2013). In addition, primary metabolites contents and the phytochemistry of plants are regulated by genetic and environmental conditions (Samyuni and Supriyadi 2015; Caretto et al. 2015). 
Rice hulling is a process used to loosen the pericarp from whole rice until the white and bright endosperm is obtained (Purwani et al. 1997). Rice hulling generates 25\% husk, $8 \%$ rice bran, $2 \%$ rice polish, and $65 \%$ refined rice: however, it also results in the loss of proteins, lipids, vitamins, and minerals in the aleurone (Haryadi 2006; Haryadi 2008). The nutritional content and utilization of rice have been widely studied but there are still local black rice cultivars in Indonesia that have not been studied. In fact, the high nutrient content of local black rice and its bioactive compounds has the potential to be developed as functional food. Therefore, this study was conducted to analyze the macronutrient (carbohydrate, lipid, protein, moisture, ash, and energy content) and minerals ( $\mathrm{Ca}, \mathrm{Fe}$, and $\mathrm{Zn}$ ) composition of whole rice, refined rice, and rice bran of five local black rice cultivars in Indonesia (Cempo Ireng "Seyegan", Melik "Bantul”, Toraja, Woja Laka, and Wedomartani).

\section{MATERIALS AND METHODS}

\section{Materials}

Whole rice samples were obtained in a market produced by local farmers who planted the black rice cultivars of Woja Laka (originally from East Nusa Tenggara but planted in Malang), Toraja (originally from South Sulawesi but planted in Bandar Lampung), Melik "Bantul" (originally planted in Bantul), and Cempo Ireng "Seyegan" and Wedomartani (originally planted in Sleman, Yogyakarta). These samples were polished to obtain refined rice and rice bran as by-products using 60 and 80 mesh sizes. All rice samples were planted from July to December 2015 and collected in February 2016 (Rukmana et al. 2016; Rukmana et al. 2017).

\section{Proximate analysis}

Macronutrient composition was determined by proximate analysis as described earlier (Oko et al. 2012), including the level of proteins, lipids, moisture, and carbohydrates and ash contents by micro-Kjeldahl, Soxhlet extraction, oven, and furnace incineration, and by different calculations. The total energy of black rice cultivars was calculated using the following formula:

Energy $(\mathrm{Cal} / 100 \mathrm{~g})=($ protein $\times 4.27)+($ lipid $\times 9.05)+$ (carbohydrate $\times 3.85)($ AOAC 2000)

\section{Mineral (Ca, Fe, and $\mathrm{Zn}$ ) analysis}

Mineral content ( $\mathrm{Ca}, \mathrm{Fe}$, and $\mathrm{Zn}$ ) was analyzed using an atomic absorption spectrophotometer ContrAA 300 (Analytik Jena, Germany). The destruction method was performed according to previous research using nitric acidperchloric acid (Gonzalez and Herrador 2007). The spectrophotometer was calibrated with a $100 \mathrm{ml}$ standard solution of calcium, iron, and zinc using different dilutions. The contents of $\mathrm{Ca}, \mathrm{Fe}$, and $\mathrm{Zn}$ were analyzed at wavelengths of 422,248 , and $213 \mathrm{~nm}$, respectively. A calibrated curve was obtained and used to determine the levels of $\mathrm{Ca}, \mathrm{Fe}$, and $\mathrm{Zn}$ of rice samples using a linear regression equation.

\section{Data analysis}

The experimental design of this study was the completely randomized design with the parameters were black rice cultivars and rice components. Thus, according to the treatment design, data were statistically analyzed using the one-way analysis of variance (ANOVA), followed by Duncan multiple range tests using the SPSS program, version 25 (SPSS Inc., Wacker Drive, Chicago, IL, USA). Results were considered to be statistically significant at $\mathrm{p}<0.05$.

\section{RESULTS AND DISCUSSION}

\section{Macronutrient composition of local black rice cultivars and rice components}

Results of the proximate analysis of local black rice cultivars and rice components are shown in Figure 1. The contents of moisture, ash, proteins, lipids, carbohydrates, and total energy of the five rice cultivars were in the range of $12.20-13.79 \%, 0.21-0.36 \%, 7.12-9.10 \%, 1.97-3.23 \%$, $61.79-65.58 \%$, and 290.90-308.59 cal/100g, respectively. The contents of moisture, ash, proteins, lipids, carbohydrates, and total energy of rice components were in the range of $10.62-15.26 \%, 0.88-5.76 \%, 7.13-11.49 \%$, $0.76-6.86 \%, 54.40-67.89 \%$, and $280.15-328.19 \mathrm{cal} / 100 \mathrm{~g}$, respectively. Almost all of the highest macronutrient levels were found in rice bran, except ash and carbohydrate content, which were found in refined rice. Results of the One-way ANOVA test revealed that all macronutrient contents in black rice cultivars and rice components were varied. Duncan's multiple range tests showed there was significance of each macronutrient content in black rice cultivars and rice components $(\mathrm{p}<0.05)$. Only Toraja black rice had highest macronutrient value in all rice components parameters, such as whole rice, refined rice, and rice bran. In each cultivar, rice bran had significant protein, lipid, moisture, and total energy value, whereas almost all significant ash content and carbohydrate were found in refined rice.

\section{Mineral (Ca, Fe, and $\mathrm{Zn}$ ) content of local black rice cultivars and rice components}

Figure 2 presents the levels of $\mathrm{Ca}, \mathrm{Fe}$, and $\mathrm{Zn}$ of local black rice cultivars and rice components. Calcium, iron, and zinc levels of rice cultivars were in the range of $347.82-60.70, \quad 30.30-21.35$, and $20.25-6.45 \mathrm{mg} / \mathrm{kg}$, respectively. Meanwhile, the levels of calcium, iron, and zinc in rice components were in the range of 347.82-60.70, $51.87-19.19$, and $80.61-3.22 \mathrm{mg} / \mathrm{kg}$, respectively. The highest mineral $(\mathrm{Ca}, \mathrm{Fe}$, and $\mathrm{Zn})$ levels were found in rice bran. According to the results of One-way ANOVA test, almost all mineral parameters showed variations in rice cultivars, except $\mathrm{Ca}$ content in whole and refined rice, also $\mathrm{Fe}$ content in refined rice. Duncan's multiple range tests showed there was significance of each macronutrient content in rice components, but not for $\mathrm{Ca}$ content in whole and refined rice, also Fe content in refined rice $(\mathrm{p}<0.05)$. In each cultivar, rice bran had significant mineral value. 

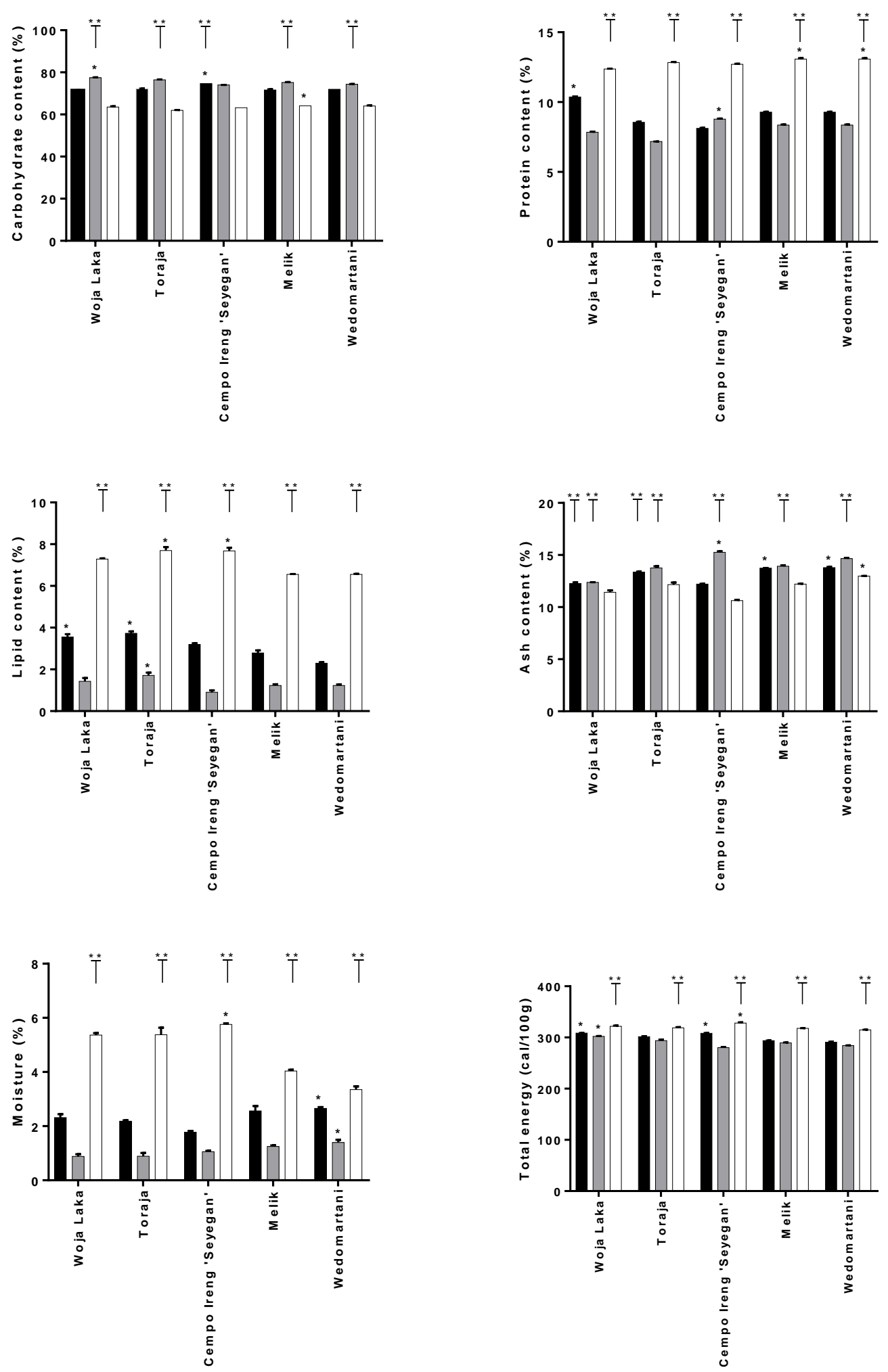

Figure 1. Macronutrient content of local black rice cultivars and rice components was carried out by proximate analysis. X axis: black rice cultivars and error bar indicate SD. *) Indicating significantly different value for rice components $(\mathrm{p}<0.05)$, **) Indicating significantly different value for black rice cultivars ( $<<0.05$ ). $\square$ : whole rice, $\square$ : refined rice, $\square$ : rice bran 

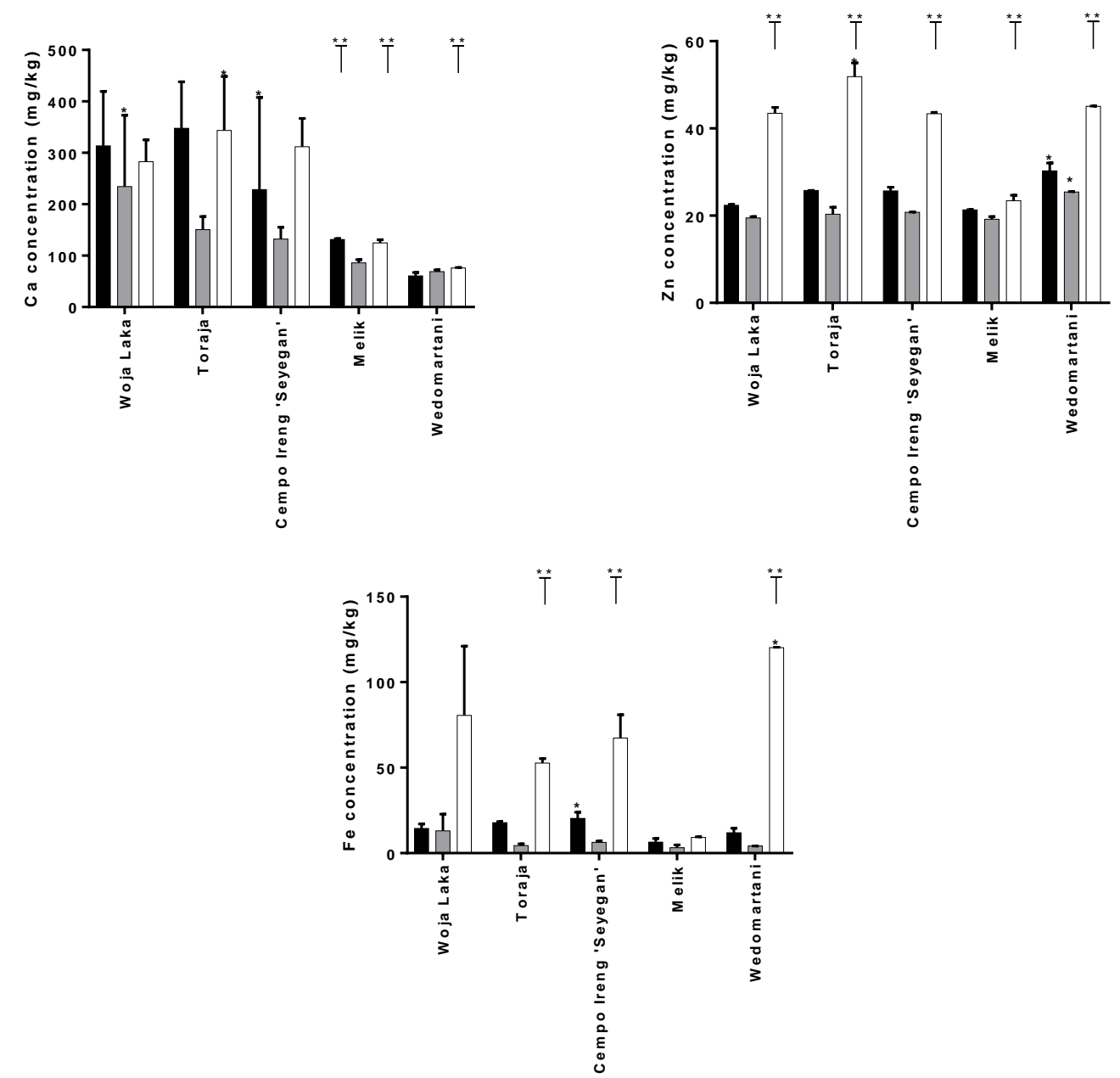

Figure 2. Minerals content of local black rice cultivars and rice components was carried out by atomic absorbance spectrophotometry. $\mathrm{X}$ axis: black rice cultivars and error bar indicate SD. *) Indicating significantly different value for rice components $(\mathrm{p}<0.05)$, **) Indicating significantly different value for rice cultivars ( $\mathrm{p}<0.05)$. $\mathbf{\square}$ : whole rice, $\square$ : refined rice, $\square$ : rice bran

\section{Discussion}

Macronutrient levels of five local black rice cultivars

The highest moisture content among the whole rice cultivars was found in Wedomartani, followed by Melik "Bantul", Toraja, and Woja Laka, whereas the lowest content was found in Cempo Ireng "Seyegan". Meanwhile, the highest moisture in refined rice was Wedomartani and Cempo Ireng"Seyegan" in rice bran. The process of rice harvesting is known to affect moisture variability of rice (Asaduzzaman et al. 2013). It also related to storage conditions because long-term preservation from insects and microorganisms requires that moisture content be controlled at approximately 12\% (Cogburn 1985). This research samples were polished to obtain refined rice and rice bran as by-products using 60 and 80 mesh sizes and were stored in a plastic bag. Meanwhile, the highest ash content in whole rice among the black rice cultivars was found in Wedomartani, Melik "Bantul", Woja Laka, and Toraja, whereas the lowest content was found in Cempo Ireng "Seyegan". The highest ash content in refined rice was Cempo Ireng "Seyegan", while rice bran is Wedomartani. Ash is one of the parameters in the proximate analysis that indicates a non-aqueous residue remaining after burning (Fairulnizal et al. 2014).

The highest protein content in whole rice was found in Woja Laka, followed by Melik "Bantul", Wedomartani, and Toraja, whereas the lowest protein content in Cempo Ireng "Seyegan". Meanwhile, Cempo Ireng "Seyegan" was the highest protein content in refined rice, while Melik and Wedomartani were in rice bran. The five local black rice cultivars showed an intermediate protein content compared to that in Cerealia whose protein content has been reported to be $6 \%-15 \%$, with the primary protein component being glutelin (McKevith 2004). Variability of macronutrient contents may be caused by interaction between genetic and environmental factors. It has been reported that protein variability in local plant foods can be caused by fluctuations in ecological and climate factors such as temperature, rainfall, soil water content, fertilizer, soil minerals, and other biotic parameters (Greenfield and Southgate 1992; Barikmo et al. 2004). The five local black rice were obtained in a different location, Woja Laka was originally from East Nusa Tenggara but planted in Malang, Toraja was originally from South Sulawesi but planted in 
Lampung, Melik "Bantul" was originally and planted in Bantul, and Cempo Ireng "Seyegan" and Wedomartani was originally planted in Sleman. Kristamtini et al. (2012) reported that the genetic relationship of 11 black rice landraces and 2 white rice from Yogyakarta and surrounding areas were divided into 5 groups. Kristamtini et al. (2014) also reported about genetic variability of 11 local Indonesian black rice based on pericarp color parameters and total anthocyanin content. In aromatic rice varieties, protein variations may be caused due to additional nitrogen content from fertilizers and planting time (Buresova et al. 2010). In the present study, the highest lipid content in whole rice was found in Toraja, Woja Laka, Cempo Ireng "Seyegan", and Melik "Bantul", whereas the lowest content was found in Wedomartani. Toraja had the highest protein level in each component of rice, such as whole rice, refined rice, and rice bran. The five local black rice cultivars were found to have a higher lipid content than that in Cerealia whose lipid content has been reported at $1-3 \%$, with the major unsaturated fatty acid in the rice oil being linoleic acid (McKevith 2004).

The cultivar Cempo Ireng "Seyegan" had the highest carbohydrate content in whole rice, followed by Woja Laka, Toraja, and Wedomartani, whereas the lowest content was found in Melik "Bantul". Meanwhile, Woja Laka had the highest carbohydrate content in refined rice, while Melik in rice bran. The highest total energy content in whole rice among the rice cultivars was found in Woja Laka, followed by Cempo Ireng "Seyegan", Wedomartani, and Toraja, whereas the lowest content was found in Melik "Bantul". Meanwhile, Woja Laka had the highest total energy in refined rice, while Cempo Ireng "Seyegan" in rice bran. Rice carbohydrates are primarily composed of starch, which contains amylose and amylopectin that regulate the physicochemical and cooking characteristics (Saikia et al. 2012).

Compared to several researches conducted by Kereh (2016), Ratnaningsih (2010), Hartati (2013), Mangiri (2016), and Murdifin (2015) to several black rice cultivars such as Enrekang, Melik, Cempo Ireng, and Wulung, the samples tend to have lower carbohydrate while protein and lipid have average percentages. Research conducted by Kereh showed black rice cultivated in Enrekang, South Sulawesi had carbohydrate, protein, and lipid with percentages such as $83.3 \%, 8.2 \%$, and $2.2 \%$, respectively. Research on 'Melik', 'Cempo Ireng', and 'Wulung' described varied number of carbohydrates, protein, and lipid of $72.49-83.94 \%, \quad 8.40-10.44 \%$, and $2.33-2.88 \%$, consecutively. Black rice 'Wulung' from Surakarta ever reported by Hartati (2013) showed $64.98 \%$ carbohydrate, $15.41 \%$ protein, and $4.23 \%$ lipid. Black rice 'Toraja' was reported by Mangiri (2016) had 1.04\% protein, 1.9\% lipid, and $85 \%$ carbohydrate. Meanwhile, macronutrient of several black rice cultivated in South Sulawesi had 1.06$2.78 \%$ lipid, $7.40-14.02 \%$ protein, and $71.29-77.14 \%$ carbohydrate.

\section{Mineral content of five local black rice cultivars}

The cultivar Toraja showed the highest calcium content in whole rice, followed by Woja Laka, Cempo Ireng
"Seyegan", and Melik "Bantul", whereas the lowest content was found in Wedomartani. An earlier study about soil minerals had reported that the levels of $\mathrm{Ca}, \mathrm{Mn}, \mathrm{Fe}$, $\mathrm{Co}$, and $\mathrm{Zn}$ in Lampung were higher in the dry season than the in the rainy season, and the highest levels of minerals in Lampung soil were those of $\mathrm{Ca}, \mathrm{Fe}$, and $\mathrm{Zn}$ (Suhariyono and Menry 2005). The cultivar Cempo Ireng "Seyegan" showed the highest iron content, followed by Toraja, Woja Laka, and Wedomartani, whereas the lowest content was found in Melik "Bantul". Past research has revealed that there is a linkage between high iron and zinc content in aromatic rice varieties (Graham et al. 2001). Black rice had higher mineral contents than white rice, such as $\mathrm{Fe}, \mathrm{Zn}$, $\mathrm{Mn}$, and $\mathrm{P}$, and the mineral content variability depended on the variety and the soil of the planting area (Gangmei and George 2017).

The highest zinc content was found in Cempo Ireng "Seyegan" followed by Toraja, Woja Laka, and Wedomartani, whereas the lowest content was found in Melik "Bantul". Several factors are known to contribute to zinc contents of rice, including genetic and environmental and planting management (Allard 1960; De Datta et al. 1987; Dey and Hossain 1995). It has been reported that dry conditions with low rainfall intensity result in a decrease of mineral contents in soil and plants (Prabowo et al. 1984). A study on 220 rice varieties demonstrated a wide variation in the contents of zinc $(2.1-39.4 \mu \mathrm{g} / \mathrm{g})$ and iron (5.1-441.5 $\mu \mathrm{g} / \mathrm{g})($ Brar et al. 2011).

Compared to research from Raghuvanshi et al. (2017), the samples had calcium, zinc, and iron content higher than red rice grown in Tarai region of Uttarakhand with 13.45 $\mathrm{mg}$ iron, $8.71 \mathrm{mg}$ calcium, and $1.91 \mathrm{mg}$ zinc. Black rice mineral abundance such as $\mathrm{Fe}, \mathrm{Zn}, \mathrm{Mn}$, and $\mathrm{P}$ may have a varying content due to varieties and soil type (Qiu et al. 1993; Liu et al. 1995; Zhang 2000). A research conducted by Apridamayanti et al. (2017) showed the level of Ca, P, and Fe of black rice 'Cempo Ireng' were $38.45 \pm 1.86 \mathrm{ppm}$; $22,565.5 \pm 2.314 \mathrm{ppm} ; 91.46 \pm 4.07 \mathrm{ppm}$, respectively. The samples had lower calcium content than those reported by Kang et al. (2011) in five black rice cultivars from Korea with $315.50 \pm 2.12-4034.00 \pm 1.41$ ppm of Ca content.

\section{Macronutrient and mineral contents of rice components}

The highest ash and carbohydrate contents among the rice components were found in refined rice, whereas the lowest contents were found in rice bran. Meanwhile, rice bran had the highest contents of moisture, proteins, lipids, and total energy, whereas the lowest contents were in refined rice. All minerals content $(\mathrm{Ca}, \mathrm{Zn}, \mathrm{Fe})$ was abundance on rice bran whereas the lowest contents were in refined rice. Rice bran is a by-product of rice processing that comes from the aleurone layer where amino acids are stored (Astawan 2004; McKevith 2004). Rice processing affects the quality and nutritional profile of rice, including minerals and phytochemicals (Mohapatra and Bal 2010).

Rice is one of the sources of complex carbohydrates to fulfill energy requirements. More than two billion Asian people fulfill $60 \%-70 \%$ of their energy intake from rice and its products (FAO 2004). However, nutrient loss occurs during milling and polishing for removing the outer rice 
husk and bran to obtain the white rice grains (Kennedy and Burlingame 2003). Furthermore, milling and polishing reduce $67 \%$ of vitamin $\mathrm{B} 3,80 \%$ of vitamin $\mathrm{B} 1,90 \%$ of Vitamin B6, $50 \%$ of manganese, $50 \%$ of phosphorus, $60 \%$ of iron, and all the dietary fibers and essential fatty acids (Babu et al. 2009).

The chemical composition of rice differs due to varieties, type of soil, and manufacturing. Nutrient losing in manufacturing may cause by rice milling, storage, and cooking (Abbas et al. 2011). Polishing of rice decreases the protein, fat, ash, and dietary fiber contents as the bran is removed including aleurone while the availability of carbohydrates increased (Shobana et al. 2011). Minerals, vitamins, fat, and fibers are abundant in rice bran layer while protein and fats in embryo of the rice (Roy et al 2008; Paiva et al. 2016; Itani et al. 2002). Moisture of rice is reduced by heat while fat and ash content by polishing and parboiling (Monks et al. 2013; Lamberts et al. 2007; Paiva et al. 2016; Heinemann et al. 2005). Polishing of rice decreases the amount of protein and increases the amount of carbohydrates. A lower protein loss in pigmented rice may be inferred that proteins in endosperm are higher than that in the bran (Lamberts et al. 2007; Paiva et al. 2016). Carbohydrate content is increased due to aleurone and germ behind the starchy endosperm diminished (Reddy et al. 2017).

In summary, this study demonstrated that there are variations in the contents of macronutrients and several minerals in the black rice cultivars and rice components. In each cultivar, rice bran had significant differences in protein, lipid, moisture, total energy, and minerals $(\mathrm{Ca}, \mathrm{Fe}$, $\mathrm{Zn}$ ) values, whereas refined rice had significant differences in ash content and carbohydrate.

\section{ACKNOWLEDGEMENTS}

The authors would like to thank and appreciate the Ministry of Research, Technology and Higher Education, the Republic of Indonesia, for financial support of this study by "Bantuan Penelitian Pendidikan Tinggi Negeri Berbadan Hukum" (BPPTNbh)", Faculty of Biology Universitas Gadjah Mada 2016 with grant number UGMBIO/HP-BPPTNbh/30/2016. Many thanks to Nyoman Yudi Antara for valuable statistics analysis suggestions.

\section{REFERENCES}

Abbas A, Murtaza S, Aslam, F, Khawar A, Rafique S, Naheed S. 2011. Effects of processing on nutritional value of rice (Oryza sativa) World J Med Sci 6 (2): 68-73.

Allard RW. 1960. Principle of Plant Breeding. John Wiley \& Sons Inc, New York.

AOAC International. 2000. Official Methods of Analysis 17th Ed. AOAC, Washington DC

Apridamayanti P, Pratiwi R, Purwestri YA, Tunjung WAS, Rumiyati. 2017. Anthocyanin, nutrient contents, and antioxidant activity of black rice bran of Oryza sativa L. 'Cempo Ireng' from Sleman, Yogyakarta, Indonesia. Indones J Biotechnol 22 (1) 49-54. DOI: DOI 10.22146/ijbiotech.26401

Asaduzzaman EH, Sorifa A, Jiaur R, Kamrul H, Ali, Maruf A. 2013. Comparisons of physiochemical, total phenol, flavonoid content and functional properties in six cultivars of aromatic rice in Bangladesh. Afr J Food Sci 7 (8): 198-203. DOI: 10.5897/AJFS2013.1001

Astawan M. 2004. Keep Healthy with Processed Food Products. Tiga Serangkai, Solo. [Indonesian]

Babu PD, Subhasree RS, Bhakyaraj R, Vidhyalakshmi R. 2009. Brown rice-beyond the color reviving a lost health food - A review. Am-Eur J Agron 2 (2): 67-72.

Barikmo I, Ouattara F, Oshaug A. 2004. Protein, carbohydrate and fiber in cereals from Mali - How to fit in a food composition table and database. J Food Compos Anal 17: 291-300. DOI: 10.1016/j.jfca.2004.02.008

BB Biogen. 2010. Potency of Indonesian local black rice. Warta Penelitian dan Pengembangan Pertanian 32 (1): 9-10. [Indonesian]

Brar B, Jain S, Singh R, Jain RK. 2011. Genetic diversity for iron and zinc contents in a collection of 220 rice (Oryza sativa L.) genotypes. Indian J Genet Plant Breed 71 (1): 67-73.

Budiman A, Arisoesilaningsih E, Wibowo RBE. 2012. Growth adaptation of two Indonesian black rice origin NTT cultivating in organic paddy field, Malang, East Java. J Trop Life Sci 2 (3): 4. DOI: $10.11594 /$ jtls.02.03.04

Buresova I, Sedlackova I, Famera O, Lipavsky J. 2010. Effect of growing conditions on starch and protein content in triticale grain and amylose content in starch. Plant Soil Environ 56: 99-104. DOI: 10.17221/123/2009-PSE

Caretto S, Linsalata V, Colella G, Mita G, Lattanzio V. 2015. Carbon fluxes between primary metabolism and phenolic pathway in plant tissues under stress. Int J Mol Sci 16: 26378-26394. DOI: 10.3390/ijms161125967

Cogburn RR. 1985. Rough mc storage. In: Juliano BO (ed) Rice Chemists and Technology. Second Ed. The American Association of Cereal Chemist, St Paul, MI, USA.

De Datta SK, Gomez KA, Herdt RW, Barker R. 1987. A Handbook on the Methodology for an Integrated Experiment-Survey on Rice Yield Constraints. The International Rice Research Institute, Los Banos.

Dey MM, Hossain M. 1995. Yield potential and modern rice varieties: An assessment of technological constraints to increase rice production. Proceeding of the Final Workshop Projections and Policy Implications and Medium and Long-term Rice Supply and Demand Project. China, Beijing, 23-26 April 1995.

Fairulnizal M, Norhayati MN, Zaiton MK, Norliza A, Rusidah AH, Aswir S, Suraiami AR, Mohd Naeem M, Jo-Lyn, A, Azerulazree A, Vimala J, Mohd B, Zainuldin T. 2014. Nutrient content in selected commercial rice in Malaysia: An update of Malaysian food composition database. Int Food Res J 22 (2): 768-776.

Food and Agriculture Organization (FAO). 2004. Codex Alimentarius: food hygiene basic texts. Food and Agriculture Organization of the United Nations, Viale delle Terme di Caracalla, Rome, Italy.

Gangmei TP, George PJ. 2017. Black rice CV. 'Chakhao Amubi' (Oryza sativa L.) Response to organic and inorganic sources of nutrients on growth, yield and grain protein content. J Pharmacognosy Phytochem 6 (4): $550-555$.

Gonzalez AG, Herrador MA. 2007. A practical guide to analytical method validation including measurement uncertainty and accuracy profiles. Trends Anal Chem 26: 227-238. DOI: 10.1016/j.trac.2007.01.009

Graham RD, Welch RM, Bouis HE. 2001. Addressing micronutrient malnutrition through enhancing the nutritional quality of staple foods: Principles, perspectives and knowledge gaps. Adv Agron 70: 77-142. DOI: 10.1016/S0065-2113 (01)70004-1

Greenfield H, Southgate DAT. 1992. Food Composition Data. Production Management and Use. Elsevier Science Publishers Ltd., Great Yarmouth, Norfolk.

Hartati S. 2013. Effect of processing on the content of polyphenol and anthocyanin wulung rice potential as food diet for diabetes mellitus sufferers. J Pangan Gizi 4 (7). DOI: 10.26714/jpg.4.1.2013.\%25p [Indonesian]

Haryadi. 2008. Rice Processing Technology. Gadjah Mada University Press. Yogyakarta. [Indonesian]

Haryadi. 2006. Rice Processing Technology. Gadjah Mada University Press, Yogyakarta. [Indonesian]

Heinemann RJB, Fagundes PL, Pinto EA, Penteado MVC, LanferMarquez UM. 2005. Comparative study of nutrient composition of commercial brown, parboiled and milled rice from Brazil. J Food Comp Anal 18 (4): 287-296. DOI: 10.1016/j.jfca.2004.07.005

Indrasari SD, Purwani EY, Wibowo P, Jumali. 2008. Rice glycemic index value of several rice varieties. Penelitian Pertanian Tanaman Pangan 27 (3): 127-134. [Indonesian] 
Itani T, Tamaki M, Arai E, Horino T. 2002. Distribution of amylose, nitrogen, and minerals in rice kernels with various characters. J Agric Food Chem 50 (19): 5326-5332. DOI: 10.1021/jf020073x

Kang, Mi-Young, Kim Joo-Hee, Rico CW, Nam Seok-Hyun. 2011. A comparative study on the physicochemical characteristics of black rice varieties. Int Food Properties 14 (6): 1241-1254. DOI: 10.1080/10942911003637350

Kennedy G, Burlingame B. 2003. Analysis of food composition data on rice from a plant genetic resources perspective. Food Chem 80 (4): 589-596.

Kereh BC, Mayulu N, Kawengian SE. 2016. Overview of nutritional substances in black rice (Oryza sativa L.) Enrekang varieties. J e Biomed (EBM) 4 (1): 1-7. DOI: DOI: 10.35790/ebm.4.1.2016.11053 [Indonesian]

Kristamtini. 2011. Study of rice and chrysanthemum seed production systems in DIY. BPTP, Yogyakarta.

Kristamtini, Taryono, Basunanda P, Murti RH, Supriyanta. 2012. Morphological of genetic relationships among black rice landraces from Yogyakarta and surrounding areas. ARPN J Agric Biol Sci 1990-6145.

Kristamtini, Taryono, Basunanda P, Murti RH. 2014. Genetic diversity of local black rice cultivars based on microsatellite markers. J AgroBiogen 10 (2): 69-76. [Indonesian]

Kristamtini, Widyayanti S, Sutarno, Sudarmaji. 2009. Genetic diversity of five local cultivars of black rice from Yogyakarta based on morphological properties. Prosiding Seminar Nasional Sumber Daya Genetik Pertanian. Yogyakarta. [Indonesian]

Kushwaha UKS. 2016. Black Rice: Research, History and Development. Springer International Publishing. Switzerland.

Lamberts L, de Bie E, Vandeputte GE, Veraverbeke WS, Derycke V, de Man W, Delcour JA. 2007. Effect of milling on colour and nutritional properties of rice. Food Chem 100 (4): 1496-1503. DOI: 10.1016/j.foodchem.2005.11.042

Liu XH, Sun CQ, Wang XK. 1995. Studies on the content of four elements $\mathrm{Fe}, \mathrm{Zn}, \mathrm{Ca}$, and $\mathrm{Se}$ in rice various areas of China. Acta Agric Universitatis Pekinensis 21 (3): 138-142.

Mangiri J, Mayulu N, Kawengian SES. 2016. Description of nutrient content in black rice (Oryza sativa L.) Ambon Pare Cultivar, South Sulawesi. J e-Biomed 4 (1). DOI: DOI 10.35790/ebm.4.1.2016.11050 [Indonesian]

Mangiri, Juwita, Nelly M, Shirley ES. 2013. Description of nutrien content in black rice (Oryza sativa L.) Pare Ambo Cultivation in South Sulawesi. Universitas Sam Ratulangi, Manado. [Indonesian]

McKevith B. 2004. Nutritional aspects of cereals. B Nutr Found Bull (29): 111-142. DOI: 10.1111/j.1467-3010.2004.00418.x

Mohapatra D, Bal S. 2010. Optimization of polishing conditions for long grain basmati rice in a laboratory abrasive mill. Food Bioprocess Technol 466-472. DOI: 10.1007/s11947-009-0254-3

Monks JLF, Vanier NL, Casaril J, Berto RM, de Oliveira M, Gomes CB, de Carvalho MP, Dias ARG, Elias MC. 2013. Effects of milling on proximate composition, folic acid, fatty acids and technological properties of rice. J Food Comp Anal 30 (2): 73-79. DOI 10.1016/j.jfca.2013.01.009

Murdifin M, Pakki E, Rahim A, Syaiful SA, Ismail, Evary YM, Bahar MA. 2015. Physicochemical properties of Indonesian pigmented rice (Oryza sativa Linn.) varieties from South Sulawesi. Asian J Plant Sci 14 (2): 59-65. DOI: 10.3923/ajps.2015.59.65

Oko AO, Ubi BE, Efisue AA, Dambaba N. 2012. Comparative analysis of the chemical nutrient composition of selected local and newly introduced rice varieties grown in Ebonyi State of Nigeria. Int J Agric For 2 (2012): 16-23. DOI: 10.5923/j.ijaf.20120202.04

Paiva FF, Vanier NL, Berrios JDJ, Pinto VZ, Wood D, Williams T, Pan J, Elias MC. 2016. Polishing and parboiling effect on the nutritional and technological properties of pigmented rice. Food Chem 191: 105-112. DOI: 10.1016/j.foodchem.2015.02.047

Prabowo A, Van Eys JE, Mathius IW, Rangkuti M, Johnson WI. 1984 Studies on the mineral nutrition on sheep in West Java. Balai Penelitian Ternak, Bogor. [Indonesian]
Pratiwi R, Purwestri YA. 2017. Black rice as a functional food in Indonesia. Funct Foods Health Dis 7 (3): 182-194. DOI: 10.31989/ffhd.v7i3.310

Purwani EY, Damardjati DS, Sarini R. 1997. Food fiber compositions of some fractions of rice soy. Agritech 17 (3): 7 . DOI: 10.22146/agritech.19336

Qiu LC, Pan J, Dan BW. 1993. The mineral nutrient component and characteristics of color and white brown rice. Chin J Rice Sci 7 (2): 95-100

Ratnaningsih N. 2010. Summary potential of black rice as source anthocyanin and its application in traditional foods. Univ. Negeri Yogyakarta, Yogyakarta. [Indonesian]

Ratnaningsih N, Ekawatiningsih P. 2010. Potential of black rice as a source of anthocyanin and its application in Yogyakarta traditional foods. Abstrak Penelitian Dosen Universitas Negeri Yogyakarta, Yogyakarta. [Indonesian]

Raghuvanshi RS, Dutta A, Tewari G, Suri S. 2017 Qualitative characteristics of red rice and white rice procured from local market of Uttarakhand: A comparative study. J Rice Res 10 (1): 49-53.

Reddy CK, Kimi L, Haripriya S, Kang N. 2017. Effects of polishing on proximate composition, physicochemical characteristics, mineral composition and antioxidant properties of pigmented rice. Rice Sci 24 (5): 241-252.

Roy P, Ijiri T, Okadome H, Nei D, Orikasa T, Nakamura N, Shiina T. 2008. Effect of processing conditions on overall energy consumption and quality of rice (Oryza sativa L.). J Food Eng 89 (3): 343-348. DOI: 10.1016/j.jfoodeng.2008.05.015

Rukmana RM, Soesilo NP, Rumiyati, Pratiwi R. 2016. The effect of ethanolic extract of black and white rice bran (Oryza sativa L.) on cancer cells. Indones J Biotechnol 21 (1): 63-69.

Rukmana RM, Soesilo NP, Rumiyati, Pratiwi R. 2017. Chemopreventive activities of 'Woja Laka' black rice bran fractions on liver carcinoma HepG2 cells. Biomed Pharmacol J 10 (4): 1677-1684.

Sa'adah IR, Supriyanta, Subejo. 2013. The variety of grain color and rice color for local varieties of black rice (Oryza sativa L.) cultivated by Sleman, Bantul, and Magelang Regency farmers. Vegetalika 2 (3): 13-20. DOI: 10.22146/veg.3994 [Indonesian]

Saikia S, Himjyoti D, Daizi S, Charu LM. 2012. Quality characterization and estimation of phytochemical content capacity of aromatic pigmented and non-pigmented rice varieties. Food Res Intl 46: 334340. DOI: 10.1016/j.foodres.2011.12.021

Samyuni EP, Supriyadi. 2015. Tolerance of black rice varieties (Oryza sativa L. indica) at different levels of drought stress. EL-VIVO 3 (2): 54-63.

Shinta, Indriyani S, Arisoesilaningsih E. 2014. Morphological variation of six pigmented rice local varieties grown in organic rice field in Sengguruh Village, Kepanjen District, Malang Regency. J Trop Life Sci 4 (2): 149-160.

Shobana S, Malleshi NG, Sudha V, Spiegelman D, Hong B, Hu FB, Willett WC, Krishnaswamy K, Mohan V. 2011. Nutritional and sensory profile of two Indian rice varieties with different degrees of polishing. Int Food Sci Nutr 62 (8): 800-810. DOI: 10.3109/09637486.2011.585962

Sompong R, Siebenhandl-Ehn S, Linsberger-Martin G, Berghofer E. 2011. Physicochemical and antioxidative properties of red and black rice varieties from Thailand, China, and Sri Lanka. Food Chem 124 (2011): 132-140. DOI: 10.1016/j.foodchem.2010.05.115

Suhariyono G, Menry Y. 2005. Analysis of the characteristics of elements in soil at various locations using XRF. Prosiding PPI - PDIPTN. Puslitbang Teknologi Maju, BATAN, Yogyakarta. [Indonesian]

Thomas R, Wan-Nadiah WA, Bhat R. 2013. Physiochemical properties, proximate composition, and cooking qualities of locally grown and imported rice varieties marketed in Penang, Malaysia. Int Food Res J 20 (3): 1345-1351.

Zhang MW. 2000. Specialty Rice and its Processing Techniques. China Light Industry Press, Beijing. 